\title{
Chemically Modified Submicron Silica Particulate Extractants for Preconcentration of Mercury(II)
}

\author{
Anupreet Kaur and L'sha Gupta* \\ Department of Chemisty: Punjabi University; Patiala, Punjab, INDIA \\ ${ }^{*}$ E-mail: anu_chem06(a) ahoo.co.in; ushagupta_doc@ajahoo.co.in \\ Received December 6, 2007
}

\begin{abstract}
A new analytical method using 1-(2-pyridylazo)-2-naphthol modified $\mathrm{SiO}_{2}$ nanoparticles as solid-phase extractant has been developed for the preconcentration of trace amounts of mercury(II) in different water samples. Conditions of the analysis such as preconcentration time, effect of $\mathrm{pH}$, sample volumes, shaking time, elution conditions and effects of interfering ions for the recovery of analyte were investigated. The adsorption

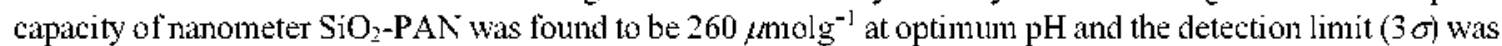
$0.48 \mu \mathrm{gL}^{-1}$. The extractant showed rapid kinetic sorption. The adsorption equilibrium of mercury(II) on nanometer $\mathrm{SiO}_{2}-\mathrm{PAN}$ was achieved just in 5 mins. Adsorbed mercury(II) was easily eluted with $5 \mathrm{~mL}$ of $6 \mathrm{M}$ hydrochloric acid. The maximum preconcentration factor was 50 . The method was applied for the determination of trace anounts of mercury(II) in various water samples and industrial effluents.
\end{abstract}

Key Words : Chemically modified $\mathrm{SiO}_{2}$-nanoparticles, 1-(2-Pyridylazo)-2-naphthol, Preconcentration and separation

\section{Introduction}

In recent years, the toxicity and effects of trace elements to the danger of public health and environment have attracted increasing attention in the fields of pollution and nutrition. Mercury and its organometallic species are considered to be highly toxic to the environment. ${ }^{1-5}$ WHO recommends a limit of $1 \mu \mathrm{gL}^{-1}$ of mercury(II) in drinking water. Direct determination of mercury at trace levels from natural water by conventional method is limited on account of its low concentration and matrix interferences. In trace analysis, therefore preconcentration or separation technique is frequently necessary to improve the detection limit and selectivity. It becomes necessary to develop an accurate selective and sensitive method for quantitative determination of mercury(II) in the environmental samples. One of the most important objectives for analytical chemists is metal quantification at trace level $\left(<\mu \mathrm{gL}^{-1}\right)$ or $n g \mathrm{~mL}^{-1}$. Despite recent progress in instrumental techniques and increases in the selectivity and sensitivity of analytical techniques, direct determination of trace elements in sample is still difficult. Therefore, preconcentration and selective separation of trace elements is very important.

The most frequently used method for preconcentration of mercury(II) from natural waters is solvent phase extraction, ${ }^{6-8}$ ion-exchange resins, ${ }^{4}$ resin chelation, ${ }^{10}$ coprecipitation $^{11}$ and solid phase extraction. ${ }^{12}$ Solid phase extraction with immobilized organic compounds is attracting great interest because of its high enrichment capability and operation simplicity. Nowadays, nanometer materials have become more important owing to its special physical and chemical propertities. Nanoparticles are cluster of atoms or molecules of metal and oxide ranging in the size from 5$5000 \mathrm{~nm}$, falling between single atom or molecule and bulk materials. One of the properties of nanoparticles is that most of atoms are on the surface. The surface atoms are unsaturated and therefore can bind other atoms that have a high chemical activity. Investigations of surface chemistry of highly dispersed oxides e.g. $\mathrm{TiO}_{2},{ }^{17.19} \mathrm{Al}_{2} \mathrm{O}_{3},{ }^{201,21} \mathrm{ZrO}_{2},{ }^{22}$ Chitosan ${ }^{23}$ and $\mathrm{CeO}_{2}{ }^{2+25}$ indicate that these materials have a very high adsorption capacity and give promising results when used for trace metal and analysis of different types of solution samples.

In this work, nanometer $\mathrm{SiO}_{2}$ was modified chemically by 1-(2-pyridylazo)-2-naphthol (PAN) as a solid-phase extractant. The adsorption behavior of analyte on nanometer $\mathrm{SiO}_{2-}$ PAN has been investigated in detail and the conditions have been optimized for the separation and preconcentration of mercury in different samples. The proposed method has been applied for preconcentration of trace mercury(II) from sample solutions and then determined by standard spectrophotometric method. Analytical precision and accuracy of the proposed method was checked and found to be quite satisfactory and the method was convenient to use.

\section{Experimental}

Instruments and apparatus. Absorbance of mercury(II) was measured with UV-VIS Shimadzu- 1700 spectrophotometer. The $\mathrm{pH}$ values were controlled by century $\mathrm{Cp}-901$ digital $\mathrm{pH}$ meter. Infrared spectra was recored on a Perkin Elmer FT-IR apparatus.

Reagents and standards. Unless otherwise stated, all reagents used were of analytical grade and all solutions were prepared with double distilled deionized water. The 3aminopropyltriethoxysilane (APTES) of GR grade was supplied by Acros Organics. 1-(2-pyridylazo)-2-naphthol (PAN) was obtained from Fluka. Nanometer $\mathrm{SiO}_{2}$ was synthesized 
according to the method reported. ${ }^{26}$ The $\mathrm{pH}$ adjustments were made with hydrochloric acid or ammonia and $\mathrm{pH}$ was maintained with acetic acid/sodium acetate buffer. Stock solution of mercury(II) was prepared, standardized before use and diluted as and when required. The glassware was washed with chromic acid and soaked in 5\% nitric acid overnight and then cleaned with double distilled water before use.

Sample preparation. Tap water samples taken from research laboratory were analyzed without pretreatment. The $\mathrm{pH}$ value was adjusted to 4 with $0.1 \mathrm{M}$ hydrochloric acid or $0.1 \mathrm{M}$ ammonium hydroxide prior to use. Industrial effluents were collected from Unitech Thermometers industry from (Delhi) and these were filtered through a $0.2 \mu \mathrm{m}$ cellulose nitrate membrane filter.

Modification process. Surface modification of $\mathrm{SiO}_{2}$ nanoparticles were performed in a $250 \mathrm{~mL}$ llask. Nanometer $\mathrm{SiO}_{2}(1 \mathrm{~g})$ was dispersed into dry toluene $(30 \mathrm{~mL})$, and then 3 -aminopropyltriethoxysilane $(4 \mathrm{~mL})$ was gradually added. with continuous stirring. The mixture was refluxed for 6 hours. The silylated nanometer $\mathrm{SiO}_{2}$ was filtered off, washed with toluene and ethanol and dried at $60^{\circ} \mathrm{C}$ for 3 hours. The product was transferred into the llask. and then $100 \mathrm{~mL}$ absolute ethanol was added followed by $20 \mathrm{~mL}$ formaldehyde, $2.5 \mathrm{~mL}$ concentrated hydrochloric acid and $1 \mathrm{~g}$ PAN and refluxed at $72^{\circ} \mathrm{C}$ for 4 hours. Reaction mixture was filtered under vaccum.

General procedure. A portion of standard or sample solution containing mercury(II) was transferred into a $10 \mathrm{~mL}$ beaker and $\mathrm{pH}$ was adjusted to the desired value and the final volume was made upto to $10 \mathrm{~mL}$ with double distilled deionized water. $50 \mathrm{mg}$ of $\mathrm{SiO}_{2}$-PAN particles were added. and the mixture was shaken vigorously for 5 mins to facilitate adsorption of mercury(II) onto the adsorbent. After this the solution was filtered through cellulose nitrate membrane filter. The concentration of mercury(II) in the solution was determined by standard spectrophotometric method. Mercury(II) retained on the adsorbent was eluted with $6 \mathrm{M}$ hydrochloric acid, and the elution was neutralized with $2 \mathrm{M}$ sodium hydroxide solution. It was filtered again, and mercury(II) in the filtrate was determined by spectrophotometric method.

\section{Results and Discussion}

SEM. The average diameter of the nanoparticles $\mathrm{SiO}_{2}$. $\mathrm{SiO}_{2}$-APTES and $\mathrm{SiO}_{2}$-PAN was $100 \mathrm{~nm}, 1 \mu \mathrm{m}$ and $2 \mu \mathrm{m}$ confirmed by Scanning Electron Microscopy. Figure 1, 2 and 3 reveals the average size of $\mathrm{SiO}_{2}$ nanoparticle. $\mathrm{SiO}_{2}-$ APTES and $\mathrm{SiO}_{2}$-PAN respectively.

FT-IR spectrum. The chemical grafting of 1-(2-pyridylazo)-2-naphthol (PAN) on the surface of nanometer $\mathrm{SiO}_{2}$ was confirmed by FT-IR spectrum. Figure 4 shows the FTIR spectra of PAN, nano-SiO $\mathrm{S}_{2}$-PAX, nano-SiO $\mathrm{S}_{2}$-APTES and nano- $\mathrm{SiO}_{2}$. Figure 4(a) reveals that main absorption peaks of nanometer $\mathrm{SiO}_{2}(3448.0,1642.5,1404,1070.2,964.2 .798 .8$ $\mathrm{cm}^{-1}$ ) are in agreement with standard spectrum of $\mathrm{SiO}_{2} .{ }^{27}$

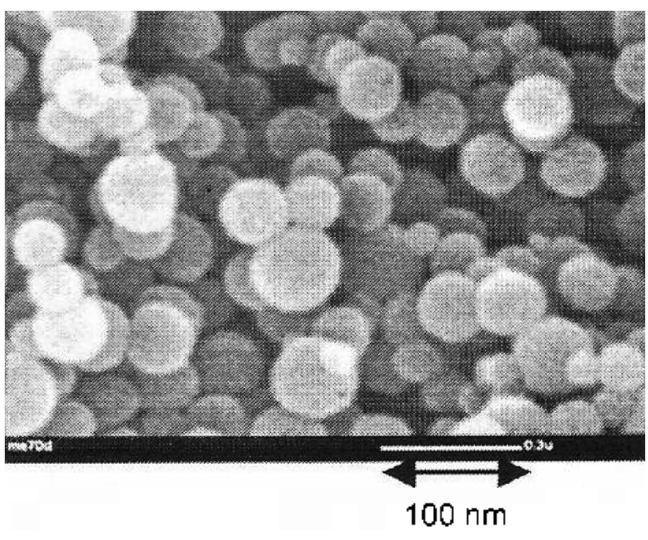

Figure 1. SEM micrograph of $\mathrm{SiO}_{2}$ nanoparticles.

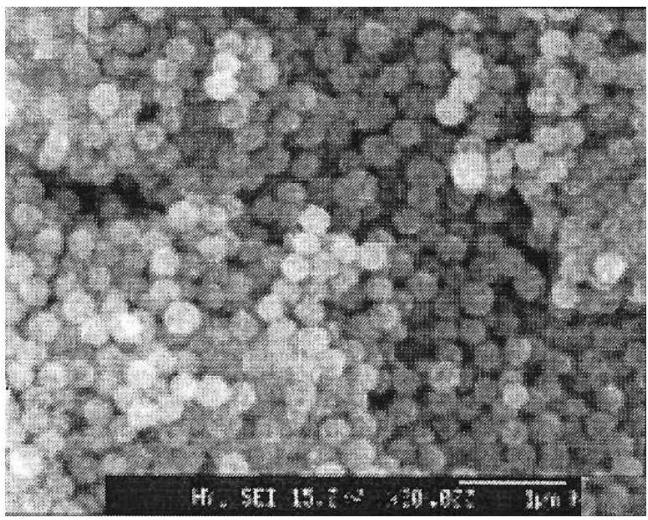

Figure 2. SEM micrograph of $\mathrm{SiO}_{2}$-APTES nanoparticles.

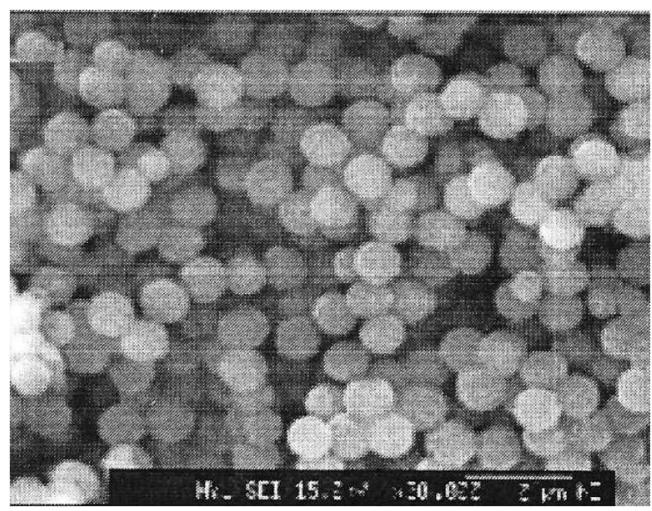

Figure 3. SEM micrograph of $\mathrm{SiO}_{2}-\mathrm{PAN}$ nanoparticle.

Many new peaks appeared in Figure 4(b) which are assigned as follows: the peak at $1683.5 \mathrm{~cm}^{-1}$ is due to $\mathrm{N}=\mathrm{N}$ stretching vibration of 1-(2-pyridylazo)-2-naphthol, the peaks of $\mathrm{C}=\mathrm{C}$ stretching vibration for the benzenoid and pyridyl unit in 1 (2-pyridylazo)-2-naphthol occurs at 1590,1540,1500 and $695.9 \mathrm{~cm}^{-1}$, the peak of $1381.6 \mathrm{~cm}^{-1}$ is due to $\mathrm{CH}_{2}$ shear deformation vibration, the peak at $1329.4 \mathrm{~cm}^{-1}$ is C-N stretching vibration for the benzenoid unit in 1-(2-pyridylazo)-2-naphthol, the peak at $1098.1 \mathrm{~cm}^{-1}$ is caused by C-O stretching vibration in 1-(2-pyridylazo)-2-naphthol. Figure 4(c) reveals that $\mathrm{C}$ - $\mathrm{H}$ stretching at $2907.2 \mathrm{~cm}^{-1}, \mathrm{NH}_{2}$ peak at $1641.3 \mathrm{~cm}^{-1}$ and $\mathrm{C}-\mathrm{O}$ stretching at $1093.5 \mathrm{~cm}^{-1}$. The above experimental results suggest that nanometer $\mathrm{SiO}_{2}$ has been 


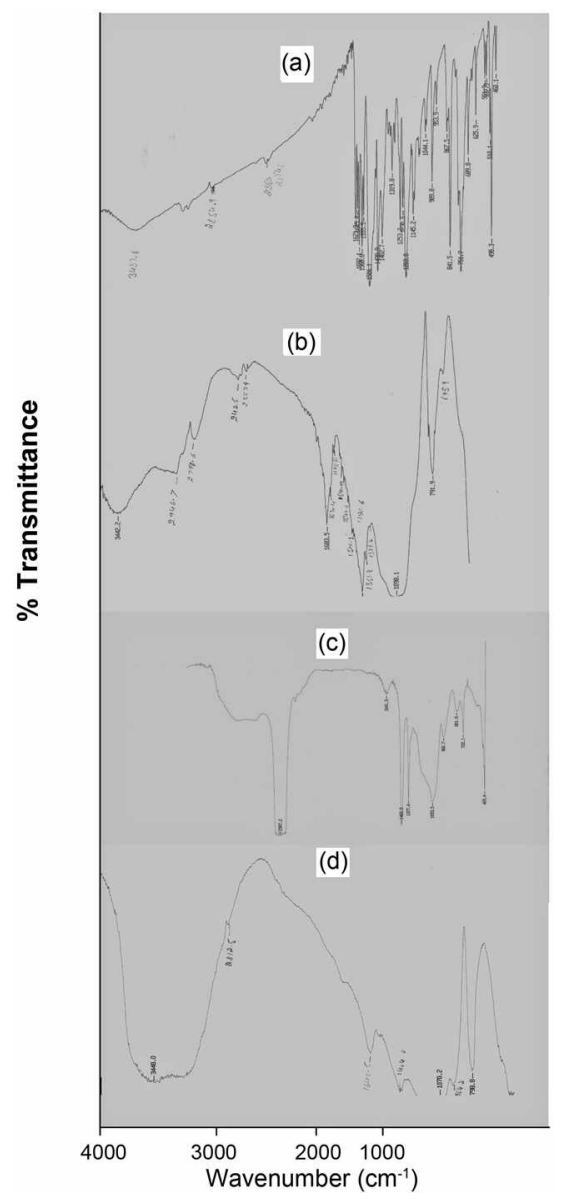

Figure 4. FTIR spectra (a) PAN (b) nanometer $\mathrm{SiO}_{-}-\mathrm{PAN}$ (c) nanometer $\mathrm{SiO}_{2}$-APTES (d) nanometer $\mathrm{SiO}_{2}$.

successfully modified by 1-(2-pyridylazo)-2-naphthol

Effect of $\mathrm{pH}$ on enrichment recovery. The adsorption of mercury(II) on nanometer $\mathrm{SiO}_{2}$-PAN was studied at different $\mathrm{pH}$ values in the range $(1.0-8.0)$ following the recommended procedure. The result shows quantitative extraction $(>95 \%)$ in the $\mathrm{pH}$ range of $4.0-8.0$. In order to avoid hydrolysis at higher $\mathrm{pH}$ values, $\mathrm{pH} 4$ was selected as the enrichment acidity for subsequent experiments. The adsorption of other metal ions on nanometer $\mathrm{SiO}_{2}$ and nanometer $\mathrm{SiO}_{2}-\mathrm{PAX}$ including $\mathrm{Mn}(\mathrm{II}), \mathrm{Co}(\mathrm{II}), \mathrm{Ni}(\mathrm{II}), \mathrm{Cu}(\mathrm{II}), \mathrm{Zn}(\mathrm{II})$, $\mathrm{Be}(\mathrm{II}), \mathrm{Cd}(\mathrm{II}), \mathrm{Hg}(\mathrm{II}), \mathrm{Pb}(\mathrm{II}), \mathrm{K}(\mathrm{I}), \mathrm{Na}(\mathrm{I}), \mathrm{Ca}(\mathrm{II}), \mathrm{Mg}(\mathrm{II})$ and Al(III) ions were also studied in range of $\mathrm{pH}$ 1.0-8.0. The basic disadvantage of nanometer $\mathrm{SiO}_{2}$ was lack of selectivity. For nanometer $\mathrm{SiO}_{2}-\mathrm{PAN}, 1.0 \mathrm{mgL}^{-1} \mathrm{Be}(\mathrm{II}), \mathrm{K}(\mathrm{I})$, $\mathrm{Na}(\mathrm{I}), \mathrm{Ca}(\mathrm{II}), \mathrm{Mg}(\mathrm{II})$ and $\mathrm{Al}(\mathrm{III})$ were not enriched at $\mathrm{pH} 4$, the extraction percentage of $1.0 \mathrm{mgL}^{-1} \mathrm{Mn}(\mathrm{II}), \mathrm{Zn}(\mathrm{II}), \mathrm{Cu}(\mathrm{II})$ and $\mathrm{Cd}(\mathrm{II})$ ions were only $10-15 \%$ and $\mathrm{Co}(\mathrm{II}), \mathrm{Pb}(\mathrm{II})$, and $\mathrm{Xi}(\mathrm{II})$ which were adsorbed on nanometer $\mathrm{SiO}_{2}-\mathrm{PAN}$ reached $25-55 \%$ at $\mathrm{pH} 4$, but they did not interfere with enrichment or determination of mercury(II). Retention is highly dependent on sample $\mathrm{pH}$ with quantitative retention requiring $\mathrm{pH}$-values over $7.5-8$, as under acidic conditions silanol groups are protonated and the ion-exchange capacity of the silica gel is greatly reduced or even reduced to zero at low pHs. PAN which was immobilized on the surface of

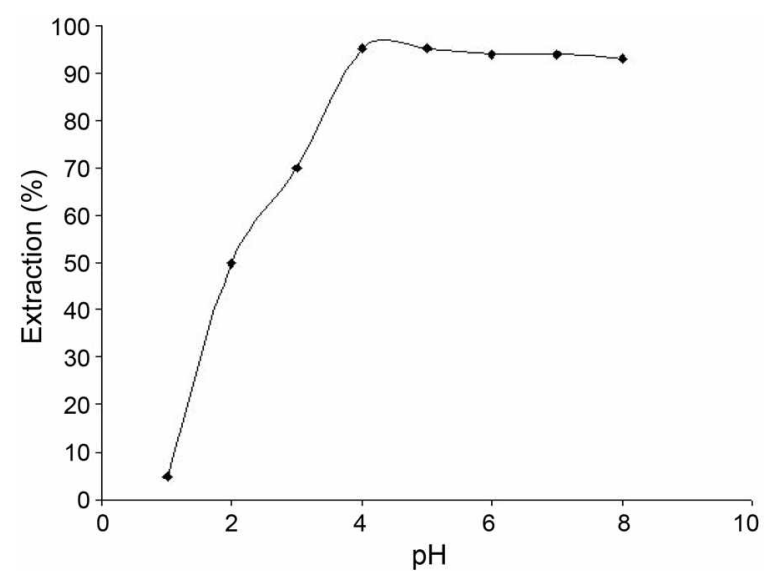

Figure 5. Effect of $\mathrm{pH}$ on analyte extraction percentage; mercury(II); $1.0 \mathrm{mgL}^{-1}$.

nanometer $\mathrm{SiO}_{2}$ changed its surface structure, and made it could rapidly adsorb metal ion even at relatively low $\mathrm{pH}$ values. ${ }^{29}$ These experiments show that nanometer $\mathrm{SiO}_{2}-\mathrm{PAN}$ offers higher selectivity for mercury(II) adsorption than untreated nanometer $\mathrm{SiO}_{2}$. The results are shown in Figure 5.

Effect of eluent concentration and volume. Since the adsorption of mercury(II) on nanometer $\mathrm{SiO}_{2}-\mathrm{PAN}$ at $\mathrm{pH}<1$ is negligible, this means elution will be favored in acidic solution. So, various concentration of hydrochloric acid (10 $\mathrm{mL}$ ) was studied for desorption of retained mercury(II). But it was found that nanometer $\mathrm{SiO}_{2}-\mathrm{PAX}$ gradually presented good dispersion in hydrochloric acid solution when the concentration of hydrochloric acid solution increased. Nanometer $\mathrm{SiO}_{2}-\mathrm{PAX}$ which was dispersed in eluent could not be removed completely through conventional centrifuge or filter. In order to resolve this problem, the elution was neutralized to $\mathrm{pH} 1.0$. Then it was filtered, and mercury(II) in the filtrate was determined by standard spectrophotometric method. ${ }^{28}$ Quantitative recovery of mercury(II) was obtained with $5 \mathrm{~mL}$ of $6.0 \mathrm{M}$ hydrochloric acid. The effect of the eluent volume on the recovery of mercury(II) was also evaluated. The results of effect of eluent concentration and volume are given in Table 1 and Table 2 respectively.

Effect of nanometer $\mathrm{SiO}_{2}$-PAN amount. To test the

Table 1. Effect of concentration of eluent $(\mathrm{HCl})$ solution on elution of mercury(II)

\begin{tabular}{lcccccc}
\hline $\begin{array}{l}\text { Concentration of } \\
\text { eluent (mol/L) }\end{array}$ & 1 & 2 & 4 & 6 & 8 & 10 \\
\hline $\begin{array}{l}\text { Recovery }(\%) \\
(n=3)\end{array}$ & 54 & 67 & 88 & 99 & 99.0 & 95.33 \\
\hline
\end{tabular}

Table 2. Effect of volume of $\mathrm{HCl}$ solution on elution of mercury(II)

\begin{tabular}{lcccccc}
\hline $\begin{array}{l}\text { Volume of } \\
\text { eluent }(\mathrm{mL})\end{array}$ & 2 & 4 & 5 & 6 & 8 & 10 \\
\hline $\begin{array}{l}\text { Recovery }(\%) \\
(n=3)\end{array}$ & 82 & 99 & 99.7 & 100.8 & 92.2 & 90.2 \\
\hline
\end{tabular}

The concentration of mercury (II) was $10 \mu \mathrm{gL}^{-1}: \mathrm{pH}=4$ 
effect of amount of extractant on quantitative retention of analyte, different amounts (10-100 mg) of nanometer $\mathrm{SiO}_{2}-$ PAX were added into the solution following the experimental method. Quantitative extraction of the mercury(II) was obtained in the range of $25-75 \mathrm{mg}$ of nanometer $\mathrm{SiO}_{2}-$ PAX. Quantitative retention was not obtained with amounts of extractant smaller than $50 \mathrm{mg}$ or larger than $75 \mathrm{mg}$. Extractor amount larger than $100 \mathrm{mg}$ may prevent the elution of the retained mercury(II). $50 \mathrm{mg}$ of nanometer $\mathrm{SiO}_{2}-\mathrm{PAN}$ as extractant was found to be sufficient for further studies.

Effect of shaking time. The adsorption of mercury(II) on $50 \mathrm{mg}$ of nanometer $\mathrm{SiO}_{2}$-PAN was studied for different shaking time (2-15 mins). The results indicated that within 5 mins the extraction percentage of mercury(II) greater than $>95 \%$ was achieved. Thus, the adsorption of mercury(II) on nanometer $\mathrm{SiO}_{2}$-PAN was found to be quite fast. This may be due to the fact that the surface atoms of nanometer $\mathrm{SiO}_{2}$ are unsaturated and tend to bind with other atoms that feature high chemical activity. The surface of nanometer $\mathrm{SiO}_{2}$ is characterized by the presence of silanol groups. which are known to be weak ion-exchangers, causing low interaction, binding and extraction of ionic species. ${ }^{30} 1-(2-$ pyridylazo-2-naphthol (PAN) which was chemically grafted on the surface of nanometer $\mathrm{SiO}_{2}$ changed its surface structure and this resulted into rapid adsorption of metal ion even at relatively low $\mathrm{pH}$ values.

Adsorption capacity $\left(Q_{s}\right)$. The adsorption capacity is an important factor as it determines how much adsorbent is quantitatively required to concentrate the analytes from a given solution. A detail study of nanometer $\mathrm{SiO}_{2}-\mathrm{PAN}$ indicated a much higher adsorption capacity ${ }^{31}$ as compared to that of nano- $\mathrm{SiO}_{2}$. A breakthrough curve was obtained by plotting the concentration $\left(\mathrm{mgL}^{-1}\right)$ vs. the $\mu \mathrm{mol}$ of mercury(II) adsorbed per gram. The breakthrough curve of Figure 6, the amount of modified nanometer $\mathrm{SiO}_{2}-\mathrm{PAN}$ for mercury(II) was found to be $260 \mathrm{mmolg}^{-1}$

Effect of the sample volume. In order to explore the possibility of concentrating low concentration of analytes from large volumes, the effect of sample volume on the retention of metal ions was also investigated. For this

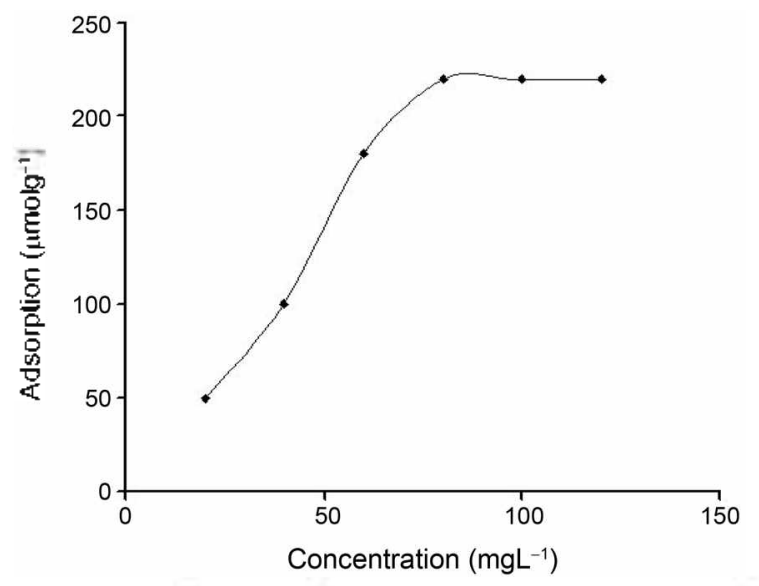

Figure 6. Adsorption capacity of mercury(II) on nanometer $\mathrm{S}_{1} \mathrm{O}_{2}-$ PAN; $\mathrm{pH} 4$; Sample volume $5 \mathrm{~mL}$.

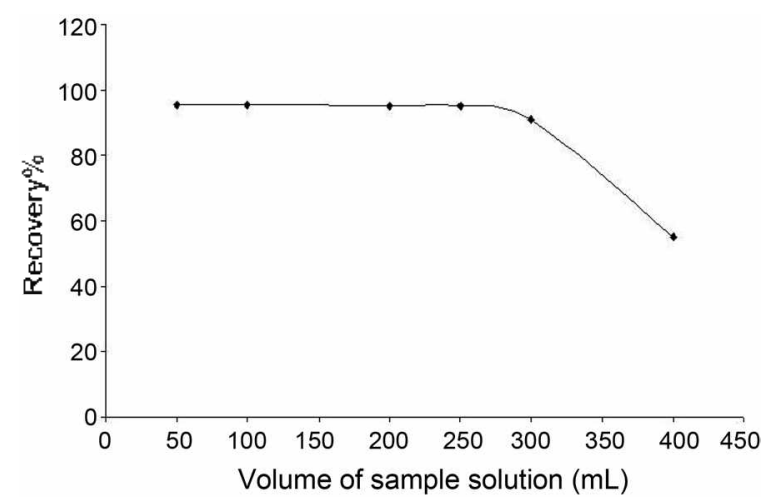

Figure 7. Effect of sample volume on analyte recovery; $\mathrm{pH} 4$; mercury (II); $2.0 \mu \mathrm{g}$.

purpose, $20,50,100,150,200,250,300$ and $400 \mathrm{~mL}$ of the sample solutions containing $2 \mu \mathrm{g}$ mercury(II) was shaken. Breakthrough volume is the maximum sample volume from which $100 \%$ recovery can be achieved. The breakthrough volume depends on the sample volume, the type and quantity of sorbent, hydrophobicity and ionizability of the analyte and $\mathrm{pH}$. The breakthrough volume for a specific mass of the sorbent $(50 \mathrm{mg})$ has been established by loading variable-volume sample of a constant concentration. The breakthrough volume was $250 \mathrm{~mL}$ in the determination of mercury(II). As shown in Figure 7, quantitative recoveries $(>95 \%)$ were obtained for sample volume of $\$ 250 \mathrm{~mL}$ for mercury(II) from sample solution.

Effect of coexisting ions. The effect of common coexisting ions on the sorption of mercury(II) was investigated ${ }^{32}$ In these experiments, solutions $10 \mu \mathrm{gL}^{-1}$ of mercury(II) that contains the added interfering ion were analyzed according to the recommended procedure. The tolerance of the coexisting ions, defined as the largest amount making the recoveries of mercury(II) less than $90 \%$. The tolerance limits were $300,40,40,200,20,100,80,90,60,90,10$, and 200 $\mathrm{mgL} \mathrm{g}^{-1}$ for $\mathrm{Ca}^{2-}, \mathrm{Mg}^{3-}, \mathrm{Zn}^{2+}, \mathrm{Cd}^{2+}, \mathrm{Al}^{3+}, \mathrm{Fe}^{2+}, \mathrm{Cu}^{2+}, \mathrm{V}^{5+}, \mathrm{Bi}^{3+}$, $\mathrm{Pb}^{2-}, \mathrm{Co}^{2+}, \mathrm{Ni}^{2-}$ respectively. Thus, the presence of major cations has no obvious influence on the determination under the optimum conditions. This is due to low adsorbing capacity on nanometer $\mathrm{SiO}_{2}$-PAN and because $\mathrm{K}^{+}$and $\mathrm{Na}^{-}$ were not adsorbed by nanometer $\mathrm{SiO}_{2}-\mathrm{PAN}$, thousand-fold excesses of $\mathrm{K}^{-}, \mathrm{Na}^{-}$had no effect on the preconcentration and determination of analyte. Apparently, the tolerance limits of foreign ions are higher than the concentrations of those ions in the other samples. Besides, a lot of $\mathrm{NO}_{3}^{-}$, $\mathrm{SO}_{4}{ }^{2-}, \mathrm{S}_{2} \mathrm{O}_{3}{ }^{2-}, \mathrm{ClO}_{4}^{-}, \mathrm{H}_{2} \mathrm{PO}_{4}^{-}, \mathrm{I}^{-}, \mathrm{CO}_{3}{ }^{2-}$ and $\mathrm{Cl}^{-}$etc did not interfere with enrichment or the determination of mercury(II).

Analytical precision and detection limits. Lnder the optimized conditions, three portions of mercury(II) standard solutions were enriched and analyzed simultaneously by the general procedure. The relative standard deviation (RSD) of the method was $1.25 \%$, indicating that the method has good precision for the analysis of trace mercury(II) from solution samples and the detection limits (3s) for mercury(II) was $0.48 \mu \mathrm{gL}^{-1}(n=3)^{3.3}$

Applications. The developed method has been applied for 
Table 3. Analytical results of samples

\begin{tabular}{lccc}
\hline Samples & Added & Results & $\begin{array}{c}\text { Recovery }(\%) \\
(n=3)\end{array}$ \\
\hline Tap Water & 0 & unfound & - \\
& 0.5 & 0.45 & 90 \\
& 1.0 & 0.92 & 92 \\
& 2.0 & 2.01 & 100.5 \\
\hline Industrial effluent & 0 & 0.80 & - \\
& 0.5 & 1.30 & 100 \\
& 1.0 & 1.84 & 105 \\
& 2.0 & 2.80 & 100 \\
\hline
\end{tabular}

Table 4. Figure of merit of comparable methods for the determination of mercury(II) by Solid-phase extraction

\begin{tabular}{llcc}
\hline Support & Reagent & LOD $(\mu \mathrm{g} / \mathrm{L})$ & Ref \\
\hline Silica Gel & 3-(-2-thioimidazolyl)propyl & 5.0 & 34 \\
Silica Gel & Dithioacetal & 10.0 & 35 \\
Silica Gel & 3-mercaptoimidazole & 5.0 & 36 \\
Silica Gel & 2-amino-1,3.4-thiadiazole & 5.0 & 37 \\
Silica Gel & Xylenol orange & 10.0 & 38 \\
Silica Gel & Methylthiosalicylate & 10.0 & 39 \\
Silica-APTES PAN & 0.48 & this work \\
nanoparticles & & \\
\hline
\end{tabular}

the determination of trace mercury(II) in the tap water and industrial effluents. For analysis, $200 \mathrm{~mL}$ of sample was extracted following the method described above. The results are given in the Table 3.

\section{Conclusions}

1-(2-Pyridylazo)-2-naphthol modified nanometer $\mathrm{SiO}_{2}$ was prepared and used as a solid sorbent to preconcentrate and separate trace mercury(II) prior to their determination by standard method. In this study, a simple, rapid, accurate, selective and reliable method for the enrichment of trace level of mercury(II) was developed using nanosized $\mathrm{SiO}_{2}$ PAN as solid phase extractant which showed great adsorption capacity and excellent selectivity. The preparation of nanometer $\mathrm{SiO}_{2}-\mathrm{PAN}$ is relatively simple and rapid. This newly developed nanosized extractant has been successfully applied to preconcentrate trace mercury(II) in tap water and industrial effluents. The method is a green approach as it does not require the use of any toxic solvents. Comparative information from some studies on preconcentration of mercury(II) by various methods for figure of merits is given in Table 4. The proposed method developed using $\mathrm{SiO}_{2}-\mathrm{PAX}$ nanoparticle had a relatively high LOD compared to other methods reported in Table 4.

\section{References}

1. Fang, G. Z.; Tan, J.; Yan, X. P. Anal. Chem. 2005, 77, 1734.

2. Zheng, H.; Chang, $\mathrm{X}$; Lian, N.; Wang, $S$; Cui, Y; Zhai, Y.;
Intern. J. Emiron. Anal. Chem. 2006, 86, 431.

3. Mercier, L.; Pinnavaia, T. J. Emiron. Sci. Technol. 1998, 32 , 2749.

4. Prado, A. G. S.; Arakaki, L. N. H.; Airoldi, C. Green Chem. 2002, $4,42$.

5. Prado, A. G. S.; Arakaki, L. N. H.; Airoldi, C. J. Chem. Soc. Dalton Trans: 2001, 2,206.

6. Liska, J. J. Chromatogr: A 1993, 655, 163.

7. Martinez, D.; Cugat, M. I.; Borrull, F.; Callul, M. J. Chromatogr: A 2000, 902,65 .

8. Bruzzoniti, M. C.; Sarzanini, C.; Mentassi, E. J. J. Chromatogr: A $2000,902,289$.

9. Cao, G H.; Fang, Z. L. Fresenits. I. Anal. Chem. 1998, 360, 156.

10. Yang, D.; Chang, X. J.; Liu, Y. W; Wang, S. Mikrochin. Acta 2004, 147, 219 .

11. Chang, X. J.; Wang, Y. M.; Zhao, R. Anal. Bioanal. Chem. 2003, $377,757$.

12. Alonso, E. V.; De Torres, A. G.; Pavon, I. M. C. Tolonta 2001, 55, 219 .

13. Henglein, A. Chem. Rer: 1989, 89, 1861.

14. Xue, Q. J.; Xu, K. Prog. Chem. 2000, 12, 431.

15. Okuyama, K.; Lenggoro, I. W. Chem. Eng. Sci. 2003, $58,537$.

16. Das, R. P.; Autand, S. Indian J. Phis. A 2004, 78, 165.

17. Liang, P.; Shi, T. Q. Intern. I. Environ. Anal. Chem. 2004, 84, 315.

18. Vassileva, E.; Furuta, N. Fresenizs. I. Ancl. Chen 2001, 370, 52.

19. Hosono, E.; Fujihara, S.; Kimura, T.; lmai, H. I. Sol-Gel Sci Technol. 2004, 29,71

20. Santos, P. S.; Lima, L. A.; Santos, H. S.; Kiyahara, P. K. An. Acud. Bross. Cienc. 1998, 70, 23.

21. Hiraide, M.; Wasawa, J. I.; Kawaguchi, H. Tolanta 1997, 44, 231.

22. Sarkar, S.; Cara, P. W.; Moneff, C. V; Subramanian, A. $J$. Chromatog: $B 2003,790,143$.

23. Oshita, K.; Xu, J. S.; Gao, Y. H.; Lee, K. H.; Oshita, M.; Motomizu, S. Bull. Chen. Soc. Jpn 2003, 76, 1555.

24. Ragai, J.; Selim, S. T. J. Colloid Interface Sci. 1987, 115, 139.

25. Blois, V; Fubini, B.; Giamello, E. Mater: Chem. Phis. 1991, 29, 153.

26. Stober, W.; Fink, A.; Bohn, E. J. Colloid Interface Sci. 1968, 26, 62 .

27. Ilverstein, R. M.; Basssler, G. C.; Morrill, T. C. Spectronetric Idenification of Organic Compounds, $3 \mathrm{rd}$ ed.; Wiley and Sons: New York, $1974 ; \mathrm{p} 115$

28. Stary, J. The Solvent Extraction of Metals Chelates, $1^{\text {st }}$ ed.; Pergamon Press: New York, 1964; 129.

29. Camel, V. Spectrochint. Acta Pont B 2003, $58,1177$.

30. Kvitek, R. J.; Evans, J. F.; Care, P. W. And. Chim. Acta 1982, 144, 93.

31. Maquieira, A.; Elmadadi, H.; Puchades, R. Anal. Chem. 1994, 66 , 3632.

32. Lian, N.; Chang, X. J.; Zhen, H.; Wang, S.; Cui, Y. M.; Zhai, Y. H. Wicrochin. Acta 2005, 151, 181.

33. Miller, J. C.; Miller, J. N. Statistical for Anatutical Chemismy; Eillis Horwood: New York, 1988; 53.

34. Newton, D. F.; Laercio, C.; Rosandre, H. Japan Science and Technologi Agency 2005, $21,1359$.

35. Mahmoud, M. E.; Gohar, G. A. Talanta 2000, 51, 77.

36. Filho, N. L. D.; Caetano, L. Anol. Sci. 2005, 21, 1359.

37. Newton, D. F.; Laercio, C.; Rosandre, H. J. Braz. Chem. Soc. $2006,17,3$.

38. Fan, J.; Lou, C.; Peng, C.; Peng, P. J. of Hazardous Materials $2007,14,5,323$.

39. Sanchezrojas, F.; De Torres, A. G. $J$ of Anatyical Atomic Spectrontery: 1998, 13,1167. 